\title{
Wykorzystanie nowych technologii informatycznych w pracy redakcji prasowej
}

Dkonujący się na przestrzeni ostatnich lat burzliwy rozwój w zakre-
sie technik komputerowych i oprogramowania stworzył dla wydawców prasy drukowanej nowe możliwości. Zmiany objęły wszystkie etapy przygotowania produktu prasowego, a więc: tworzenie materiału w edytorach tekstu, skład i korektę, cyfrowe zdjęcia, dostarczanie drogą elektroniczną wszystkich materiałów (tekst, zdjęcia) do drukarni, wykorzystywanie materiałów redakcyjnych do tworzenia witryn internetowych itd. Modernizacja i towarzyszące jej liczne przeobrażenia wymusiły ponadto nieustanną ewolucję, dostosowywanie się do aktualnych trendów i poszukiwanie innowacyjnych rozwiązań w obrębie oferowanego produktu i jego promocji. Tego typu działania mają służyć zaspokojeniu potrzeb i oczekiwań czytelników, a w konsekwencji - zwiększeniu szans na przetrwanie poszczególnych inicjatyw wydawniczych w konkurencyjnym środowisku. Podążając za innowacjami w sferze technologii, radykalnie zmieniła się struktura zatrudnienia i zasobów pracy w redakcjach, wydawnictwach i drukarniach. Zwiększenie skali technicznego wyposażenia wpłynęło równie znacząco na zmiany jakości artystycznej i graficznej gazety, w tym na poprawę czytelności druku i jakości publikowanych zdjęć. Jednocześnie wydawcy coraz większą uwagę zwracają na wygląd zewnętrzny swoich tytułów, a layout staje się często kluczowym elementem strategii zmian wprowadzanych w redakcjach. Aktualne tendencje wskazują, że dotyczy to zarówno czasopism, jak i dzienników mających już ugruntowaną pozycję na rynku. 
Cyfryzacja mediów stwarza poważne zagrożenie dla gazet w ich tradycyjnym, papierowym wydaniu'. W obliczu silnej konkurencji, głównie ze strony telewizji i Internetu, dramatycznie wzrasta presja ekonomiczna, jakiej podlegają redakcje prasowe. Bieżących informacji dostarcza przede wszystkim Internet:

Robi to szybciej i taniej niż prasa, radio i telewizja, ma większy zasięg i wachlarz środków ekspresji. Dostarcza wiadomości na zawołanie, a nie raz dziennie jak prasa lub co kilkanaście minut jak telewizja. Pozwala je stale aktualizować, a ich ilość ograniczona jest tylko pojemnością serwerów. I najważniejsze: Internet daje odbiorcy możliwość samodzielnego doboru informacji - internauta sam decyduje, o czym, jak szczegółowo i z czyjej perspektywy chce się dowiedzieć [Smoczyński 2009].

Bezpośrednim skutkiem rozwoju mediów elektronicznych jest spadek czytelnictwa równoznaczny z malejącymi wpływami z reklam. Rynek prasy wciąż boryka się z problemem utrzymania lojalności czytelników, co uwidacznia się przede wszystkim w spadku nakładów [Jung, Kowalski 2006: 133-134].

Cyberprzestrzeń jest zagrożeniem nie tylko dla utraconego przez prasę monopolu na newsy. Prasa traci też sukcesywnie przywilej komentowania i wyjaśniania. Ekonomizacja dziennikarstwa, urynkowienie pracy w mediach, mające wpływ na jakość oferowanego produktu, spowodowały, że ciężar informacyjny stopniowo przesuwa się w stronę komunikacji online. Wydawcy, w odpowiedzi na rosnącą konkurencję, coraz częściej i pewniej sięgają więc po nowe rozwiązania technologiczne. Wydania elektroniczne, strony, a nawet całe platformy internetowe to przejaw tej tendencji [Podkański 2007: 68]. Tym samym, obok tradycyjnych gatunków dziennikarskich, pojawił się hipertekst i e-gazeta. Szybki i zazwyczaj darmowy dostęp do informacji, częste aktualizacje, zamieszczanie obok tekstu filmów, animacji, linków i zakładek oznaczają dla czytelnika możliwość selekcji i szybkiego wyszukiwania potrzebnych informacji. Jak piszą Kazimierz Wolny-Zmorzyński i Andrzej Kaliszewski, hipertekst jest absolutnym zaprzeczeniem linearności w procesie komunikowania i w ogóle negacją formy ostatecznej, perfekcyjnej, zamkniętej (ale za to szybko się dezaktu-

1 Fragment poświęcony zjawisku cyfryzacji mediów został napisany we współpracy z Dagmarą Szastak-Ziębą. 
alizującej) - która była ideałem tradycyjnej prasy offline [Wolny-Zmorzyński, Kaliszewski, Furman 2006: 120].

Początkowo e-wydania miały jedynie wspierać tradycyjne wydania dzienników. Stanowiły środek promocji oraz źródło informacji o redakcji, wydawcy i działalności reklamowej. W ówczesnej postaci e-wydania były wyłącznie elektroniczną kopią wersji drukowanej, gdyż ich układ i zawartość w całości nawiązywały do gazet tradycyjnych. Wkrótce jednak zyskujące na znaczeniu portale internetowe zaczęły tworzyć własne serwisy informacyjne, które okazały się poważną konkurencją dla dzienników online. W odpowiedzi większość wydawców zaczęła traktować e-wydanie jako alternatywny dostęp do swoich czytelników [Jung, Kowalski 2006: 13]. Gazeta w elektronicznej postaci stała się odrębnym produktem, z osobną marką i innymi grupami odbiorców.

Ze względu na interaktywną zawartość dziennikarską i reklamową e-gazety stanowią istotne uzupełnienie tradycyjnych wydań (m.in. są wzbogacone o hiperłącza kierujące do plików wideo lub innych informacji). Za przygotowanie treści serwisu internetowego często odpowiadają samodzielne zespoły redakcyjne. Odrębne redakcje mają m.in. witryna „Super Expressu" (Murator SA) - Se.pl i „Gazety Podatkowej” (Wydawnictwo Podatkowe Gofin) - Gofin.pl. Wielu wydawców prasy codziennej oferuje w sieci połączenie standardowego portalu i witryny ogólnopolskiego dziennika. Przykładem specyficznej strony internetowej jest Gazeta.pl (Agora), która stopniowo odchodziła od papierowej „Gazety Wyborczej”. Jej miejsce zajął z czasem serwis Wyborcza.pl. Serwisy Gazeta.pl i Wyborcza.pl tworzą oddzielne zespoły redakcyjne, jednak wykorzystują efekt synergii. Serwis Wyborcza.pl publikuje treści zamieszczane w dzienniku, z serwisu z kolei korzysta portal Gazeta.pl. Zmiana profilu serwisu Gazeta.pl, czyli nowy layout witryny oraz wzbogacenie jej portalami społecznościowymi, materiałami lifestyle'owymi i serwisem Plotek.pl, ujawnia kolejny trend - postępującej tabloidyzacji polskich serwisów internetowych [Nowak 2008: 219].

Wydawcy liczą, że dzięki synergii między medium drukowanym a internetowym oraz wzajemnemu przenikaniu się dotychczas wyraźnie odrębnych mediów (konwergencja) zwiększy się liczba czytelników. Zabiegają więc o prenumeratorów tradycyjnego wydania, którym w zamian proponują m.in. darmowy dostęp do archiwum online. Inwestują w wydania internetowe również ze względu na możliwość oferowania produktu w cenie niemal bezpośrednich kosztów jego wytworzenia, z pominięciem 
kosztów papieru, druku i dystrybucji. Dystrybucja online wymaga posiadania odpowiednich zasobów komputerowych, serwerów i dzierżawy łączy telekomunikacyjnych, co także pochłania określone nakłady kapitałowe. Koszty te są jednak niższe niż w przypadku tradycyjnego rozprowadzania towarów, które w Polsce pochłania około 33\% ceny detalicznej gazety [Jung, Kowalski 2006: 131-132]. Istotną zaletą wydania online jest brak ostatecznego terminu ukazania się, nie ma również ograniczeń objętościowych. Zawartość może być stale modyfikowana i uzupełniana, a dzięki rozwiniętym systemom oprogramowania możliwe stało się też dokonywanie na bieżąco oceny stopnia zainteresowania odbiorców poszczególnymi tematami i autorami (sondowanie opinii, możliwość zamieszczania komentarzy przez czytelników) [Jung, Kowalski 2006: 131-132].

W 1994 roku statyczne wizytówki internetowe zaprezentowały "Gazeta Wyborcza”, „Rzeczpospolita” i „Życie Warszawy” [Hofman 2007: 205-206]. W pierwszej dekadzie istnienia polskiej e-gazety w sposobie jej funkcjonowania dokonały się głębokie przemiany ilościowe i jakościowe. "Gazeta Wyborcza" uruchomiła portal Gazeta.pl, skutecznie konkurujący pod względem liczby użytkowników serwisów informacyjnych z portalami Onet.pl i Wirtualna Polska, na stronie www.newsweek.pl są dostępne audycje nagrywane przez dziennikarzy tygodnika, m.in. czytających najciekawsze fragmenty swoich tekstów lub omawiających bieżące wydarzenia [Hofman 2007: 205-206]. Odpowiadając na trend Web 2.0, przejawiający się w dążeniu do jak największej interaktywności serwisów WWW, wydawcy uruchamiają czaty, fora, blogi, bezpłatne skrzynki poczty elektronicznej, tworzą platformy wiadomości ze zintegrowanych źródeł (w tym np. $z$ radia). Redakcja gazety może inicjować dyskusje z zaproszonymi gośćmi także w świecie wirtualnym. Rozmowy czatowe (bądź ich fragmenty), np. Cafe Wprost - prowadzone w Internecie przez opiniotwórczy tygodnik - mogą być później publikowane w prasie offline jako wywiady, debaty czy opinie. W rywalizacji prasy z mediami elektronicznymi tradycyjne dziennikarstwo wspierają również blogi, czyli autorskie strony internetowe zawierające datowane wpisy. Czas przekazu gorącego newsa za pomocą bloga i np. telewizji jest w zasadzie ten sam [Hofman 2007: 205-206]. W tygodniku „Polityka” pierwsze blogi pojawiły się w 2006 roku (m.in. Daniela Passenta, Janiny Paradowskiej). Podobnie niektórzy dziennikarze gazet codziennych (np.,"Gazety Wyborczej",,Dziennika”) prowadzą własne dzienniki internetowe. Tytuły najczęściej nawiązują do publikacji pojawiających się w wersji offline, stanowią zatem sygnał, punkt odniesie- 
nia dla czytelników. W Internecie są także zamieszczane treści niepowiązane w żaden sposób z artykułami napisanymi dla gazety lub częściej stanowiące zapowiedź bądź kontynuację publikacji prasowej. Blog pełni funkcję wizytówki dziennikarza i jego macierzystej redakcji, skłaniając tym samym czytelnika do sięgnięcia po gazetę, w której są drukowane jego teksty. Powszechną praktyką jest stałe poszerzanie oferty, np. przez uruchamianie partnerskich serwisów (jak Dziennik.pl - wyszukiwarka ofert nieruchomości Otodom.dziennik.pl, centrum finansowe Cf.dziennik.pl).

Profesjonalna realizacja zadań dziennikarskich w Internecie, związana przede wszystkim z prowadzeniem portali i wortali informacyjnych, wymaga korzystania i ciągłego dostosowywania się do zmian technologicznych, jakie zachodzą w branży informatycznej. Technologia daje wydawcom i redakcjom szerokie możliwości stosowania rozwiązań usprawniających pracę dziennikarza czy redaktora online. Dotyczy to zwłaszcza obszaru zarządzania treścią, a zatem tworzenia, aktualizacji i publikacji zawartości serwisu internetowego w postaci tekstu, zdjęć, infografik, plików multimedialnych, plików w formatach MS Office, PDF itp. Szerokie zastosowanie w zarządzaniu treścią portali czy wortali znajdują programy z grupy Content Management System (CMS). CMS to zbiór aplikacji obejmujący instrumenty informatyczne do zarządzania dokumentami (Document Management), zarządzania wiedzą (Knowledge Management), zarządzania zasobami cyfrowymi (Digital Asset Management) oraz zarządzania treścią (Enterprise Content Management). Programy te pozwalają na łatwe tworzenie serwisu oraz jego aktualizację i rozbudowę przez redakcyjny personel nietechniczny, korzystający z prostego w użyciu panelu administracyjnego dostępnego za pośrednictwem przeglądarki internetowej. Dzięki CMS kształtowanie treści serwisu WWW oraz form jej prezentacji odbywa się za pomocą łatwych w obsłudze interfejsów użytkownika, zazwyczaj $w$ postaci stron internetowych zawierających odpowiednie formularze i moduły. Podstawowym zadaniem CMS jest oddzielenie treści (zawartości informacyjnej serwisu) od wyglądu (sposobu jej prezentacji). Po wprowadzeniu nowych informacji przez uprawnionego redaktora system przenosi je do bazy danych, jednocześnie wypełniając nimi odpowiednie miejsca na stronach internetowych. Wykorzystanie szablonów stron sprawia, że zmiana koncepcji graficznej całego serwisu sprowadza się do przygotowania i wymiany szablonu. Dzięki takiemu podejściu proces publikacji w sieci staje się prosty nawet dla osób niemających wiedzy informatycznej. Jak pisze Ilona Neffe [2008: 1], aplikacje z grupy CMS - zaprojekto- 
wane przez dobrych programistów - stanowią narzędzie dla każdego, kto tylko potrafi opanować instruktaż obsługi, sprowadzający się do umiejętności zarządzania panelem administracyjnym.

Pierwsze CMS wprowadzono pod koniec lat 90. XX wieku, wraz z dynamicznymi stronami WWW. Pierwszy internetowy system zarządzania treścią wykonała amerykańska firma CNET - został on opatentowany w 1995 roku. Neffe zauważa, że [2008: 1]:

Pierwsze CMS-y umożliwiały co prawda modyfikacje stron w trybie online, ale edycji trzeba było dokonać w notatniku, co wymagało znajomości języka HTML i PHP. Obecnie nie ma już takiej potrzeby, korekty dokonujemy w edytorze, w trybie WYSIWYG. Za najistotniejsze w ewolucji tych systemów uważa się wprowadzenie szablonów, a następnie powiązanie ich z bazą danych typu MySQL (Postgres lub Oracle). Baza danych przechowuje informacje, np. o umiejscowieniu plików multimedialnych, a strona główna programistycznie posiada wyłącznie instrukcje przywołania tej informacji. Tak więc dane rozumiane jako zawartość strony (treść) oddzielone są od szablonu strony i przechowywane w bazie danych, natomiast aplikacje pracujące na serwerze pobierają te dane (według instrukcji) i wyświetlają w wyznaczonym miejscu. Wygląd strony, na którą składa się tekst i wstawione elementy, rozumiany jest jako forma i definiowany w tzw. kaskadowych arkuszach stylów (CSS).

Programy z grupy CMS znacznie ułatwiają prowadzenie serwisu internetowego gazety. Pozwalają bardzo szybko dodawać i modyfikować treść portalu, co umożliwia błyskawiczne reagowanie na wydarzenia oraz wielokrotne modyfikacje i uzupełnienia opublikowanych materiałów prasowych. Z wszystkich dostępnych w panelu administracyjnym CMS funkcji mogą korzystać uprawnieni do tego redaktorzy. Nie jest tu wymagana znajomość języka HTML, tym bardziej że wiele programów CMS oferuje użytkownikom dostęp do pomocy - wskazówek co do wykonywanych właśnie czynności. W prowadzeniu portalu nie muszą zatem uczestniczyć redakcyjni informatycy czy graficy (ich rola sprowadza się de facto do instalacji systemu oraz ustalenia zawartości witryny). Aplikacje z tej grupy dają możliwość kompletnego kierowania serwisem internetowym na wszystkich etapach pracy dziennikarskiej i redaktorskiej: od zamieszczania informacji, przez kontrolę nad miejscem jej publikacji i treścią, uzupełnianie materiału o elementy multimedialne, po archiwizację i usuwanie tekstów prasowych. Dodatkową zaletą CMS jest opcja rozbudowywania 
serwisu (np. o kolejne wersje językowe) oraz możliwość łatwej modyfikacji szablonów graficznych, nawet jeśli zmiany mają daleko idący charakter. Aplikacje do zarządzania treścią pozwalają automatycznie przebudować szatę graficzną całego portalu, bez konieczności wprowadzania zmian kolejno na poszczególnych podstronach. W praktyce oznacza to np. szansę modyfikacji layoutu serwisu na świąteczny za pomocą prostego polecenia dostępnego w panelu administracyjnym.

Oprócz ułatwień w zakresie redagowania gazetowych serwisów internetowych aplikacje z grupy CMS znajdują zastosowanie także w innych obszarach zarządzania treścią publikowaną w Internecie przez organizacje prasowo-wydawnicze. Przedsiębiorstwa medialne wykorzystują je do tworzenia poszczególnych części swoich witryn korporacyjnych, w tym portali i wortali kierowanych do różnych grup odbiorców (klientów, pracowników, reklamodawców, kontrahentów), prowadzenia elektronicznych biur prasowych czy zarządzania systemem komunikacji wizualnej wydawnictwa itp. Należy również zauważyć, że narzędzia z grupy Content Management System mogą być używane nie tylko do administrowania treścią, ale także danymi czy obiegiem dokumentów. Jako takie w praktyce funkcjonowania organizacji prasowej znajdują zastosowanie m.in. w zarządzaniu informacją, dziennikarskim researchingu i obsłudze archiwum redakcyjnego oraz planowaniu i organizowaniu pracy redakcji i pionu wydawniczego.

Przez pojęcie zarządzania informacją w organizacji prasowo-wydawniczej należy rozumieć zespół działań, tworzących funkcję informacyjną przedsiębiorstwa medialnego, tj. pozyskiwanie, przetwarzanie i dyfuzję informacji. Informacja jest źródłem inspiracji i wiedzy dziennikarzy , „tworzywem" ich codziennej pracy, produktem medialnym obecnym na łamach gazety. Ten zasób organizacji medialnej zalicza się do aktywów strategicznych, czyli tych wartości przedsiębiorstwa, które są podstawą tworzenia skutecznej strategii działania, przesądzają o sukcesie organizacji. Armin Scholl i Siegfried Weischenberg definiują dziennikarstwo jako przekazywanie społeczeństwu aktualnych wiadomości, pochodzących z różnych podsystemów systemu społecznego (np. polityki, gospodarki, sportu) po ich wcześniejszym zebraniu, selekcji i obróbce. Efekt ich pracy winien charakteryzować się nowością, faktycznością i niezależnością. W opinii Scholla i Weischenberga do podstawowych obowiązków dziennikarzy należy zbieranie, sprawdzanie, wybór i obróbka informacji oraz przystosowywanie ich do potrzeb przekazu medialnego [Michalczyk 2006: 52]. Wykonywanie tych 
czynności wymaga stworzenia w organizacji prasowo-wydawniczej sprawnie funkcjonującego systemu pozyskiwania, weryfikacji, selekcji, wymiany i archiwizacji informacji, a zatem profesjonalnego zarządzania informacją. System ten jest implementowany na różnych płaszczyznach działania organizacji (płaszczyzny organizacyjna, zasobów ludzkich, technologiczna). Zarządzanie informacją w redakcji prasowej ma służyć przede wszystkim: 1) pozyskiwaniu i utrzymywaniu nowych i jakościowo wartościowych źródeł informacji - chodzi o kreowanie oraz podtrzymywanie efektywnych kontaktów z agencjami informacyjnymi, służbami public relations, informatorami funkcjonującymi w różnych środowiskach (np. policja, wymiar sprawiedliwości, polityka, biznes); 2) tworzeniu systemu weryfikacji i selekcji informacji - chodzi o opracowanie, przekazanie do wiadomości pracowników (dziennikarzy, redaktorów) i egzekwowanie stosowania czytelnego dla użytkowników i funkcjonalnego katalogu zasad researchu. Ów katalog, spójny z misją gazety, winien być zapisany $\mathrm{np}$. w redakcyjnym style booku; 3) tworzeniu i ochronie zasobów informacji - chodzi o organizowanie i efektywne zarządzanie redakcyjnymi archiwami, wykorzystywanie systemów informatycznych usprawniających ich pracę oraz ochronę zasobów informacyjnych przed "wyciekami" czy kradzieżami danych itp.

W systemie informacyjnym organizacji prasowo-wydawniczej można wskazać dwa zasadnicze elementy: układ wejścia oraz układ przetwarzania informacji [Zygała 2007: 70-71]. Układ wejścia to rozproszona struktura tworzona przez dane i informacje wejściowe (informacje pochodzące z dokumentów, pism, przepisów prawnych itp.) oraz kanały informacyjne (informacje dostarczane przez czytelników, informatorów, ekspertów, przekazywane za pośrednictwem urządzeń telekomunikacyjnych, poczty oraz pochodzące z innych mediów). Zarządzanie informacją na etapie układu wejścia oznacza w praktyce dywersyfikacjęźródeł informacji (stwarzanie dziennikarzom warunków do pozyskiwania informacji z różnych źródeł, np. przez korzystanie z serwisów wielu agencji prasowych, czerpanie z zewnętrznych banków ekspertów, opłacanie informatorów, organizowanie dyżurów reporterskich w redakcji oraz w terenie, prenumerowanie konkurencyjnych gazet i udostępnianie ich dziennikarzom, opłacanie dostępu do zewnętrznych baz danych, encyklopedii internetowych, archiwów itd.). Jak piszą Marek Chyliński i Stephan Russ-Mohl, dobra selekcja wiadomości i tematów uda się tylko temu dziennikarzowi, który na bieżąco obserwuje wszystkie wydarzenia i korzysta przy tym z różnych źródeł informacji [Chyliński, Russ-Mohl 2006: 119]: 
Dziennikarze są [...] także odbiorcami mediów, i to korzystającymi z nich bardzo intensywnie. Ich powinnością jest codzienne czytanie, oglądanie, słuchanie. Ponieważ lista "lektur obowiązkowych" naprawdę może być imponująca, dziennikarze powinni nauczyć się odpowiednich sposobów i technik, które pomogą im nadmiar wiadomości sprowadzić do samej istoty rzeczy.

Układem przetwarzania, a zatem drugim elementem składowym systemu informacyjnego organizacji prasowej, będą urządzenia i procesy związane z zapisywaniem informacji na nośnikach, klasyfikowaniem i porządkowaniem informacji, ich weryfikowaniem i oceną oraz magazynowaniem. Profesjonalne zarządzanie informacją na tym etapie oznacza w praktyce m.in. określenie procedur i zasad przechowywania przez dziennikarzy pozyskanych danych (miejsce przechowywania, nośniki, kopie zapasowe, obowiązek dokumentowania przebiegu dyżuru reporterskiego czy rozmowy z informatorem), a także opracowanie kryteriów doboru informacji oraz stosowanych tu priorytetów (właściwa dla tabloidów sensacyjność, charakterystyczna dla dzienników newsowość i aktualność, specyficzne dla gazet lokalnych kryterium bliskości geograficzno-przestrzennej informacji). Zarządzanie informacją w układzie przetwarzania wymaga ponadto jasnego podziału kompetencji w dziedzinie "gatekeepingu", czyli procesu selekcji informacji i kierowania jej do upublicznienia. Chodzi o określenie, kto i w jakim zakresie pełni w redakcji funkcję "gatekeepera" - osoby kontrolującej przebieg informacji [Chyliński, Russ-Mohl 2006: 119].

W ramach układu przetwarzania niezwykle istotną częścią systemu informacyjnego redakcji są bazy służące przechowywaniu informacji. Niegdyś na redakcyjne archiwum składały się magazynowane w szafach tomy dokumentów i wycinków oraz segregatory ze zszywkami gazet i fotografiami. Dziś funkcję tradycyjnych archiwów pełnią informatyczne bazy danych pozwalające archiwizować informacje w wersji elektronicznej. Dzięki temu na twardych dyskach redakcyjnych komputerów - pod postacią plików tekstowych, graficznych, dźwiękowych i filmowych - są gromadzone artykuły, nagrania wywiadów, dane informatorów, zdjęcia fotoreporterskie, dokumenty, listy do redakcji, nadesłane sprostowania oraz odpowiedzi itd. Nowoczesne bazy danych, wykorzystywane w redakcyjnych archiwach, są często tworzone na podstawie programów CMS. Programy te mogą być przydatne praktycznie na wszystkich etapach zarządzania informacją: od 
jej tworzenia lub pozyskiwania, przez współdzielenie, publikowanie, archiwizowanie, po usuwanie zasobów. Aplikacje CMS umożliwiają elektroniczne przetwarzanie wszystkich dokumentów (np. tekstów, zdjęć, listów), ich archiwizację, ewidencjonowanie, automatyczne wyszukiwanie (po tytule, dacie publikacji, słowach kluczowych), konsolidację danych z różnych systemów, drążenie danych, czyli schodzenie z poziomu ogólnego do poziomu szczegółów (drill down), poszerzanie obrazu raportu i przechodzenie do bardziej ogólnego poziomu - agregacji danych (roll up), tworzenie korelacji między danymi czy nawigację kontekstową, uwzględniającą znaczenie semantyczne metadanych kontekstowych. Pozwala to zdobyć wiedzę np. o liczbie publikacji na dany temat w poprzednich latach, ich wydźwięku, liczbie i charakterze reakcji czytelniczych na tekst (w postaci listów do redakcji czy komentarzy na forum internetowym). CMS daje możliwość łatwego pozyskania niezbędnych informacji, ich obróbki i prezentacji zgodnej z potrzebami i oczekiwaniami użytkowników (dziennikarzy, fotoedytorów, infografików, służb prawnych czy marketingowych wydawnictwa), a także ograniczania liczby informacji przestarzałych. Dzięki CMS dostęp do baz danych odbywa się za pośrednictwem przeglądarki internetowej i nie wymaga szczególnych umiejętności technicznych ani zastosowania dodatkowego oprogramowania. Uzyskanie danych (zarówno ilościowych, jak i jakościowych) następuje w krótkim czasie, co z punktu widzenia specyfiki pracy w mediach ma znaczenie zasadnicze. CMS umożliwia zastąpienie lub uzupełnienie tradycyjnego, „ręcznego" sposobu przetwarzania dokumentów, co prowadzi do uproszczenia mechanizmów podziału czynności i pozwala oszczędzić czas pracowników.

Wykorzystanie nowoczesnych technologii informatycznych w redakcyjnych systemach zarządzania danymi przynosi korzyści polegające na stworzeniu rozwiązań archiwizacji informacji o następujących, pożądanych z punktu widzenia użytkownika cechach: a) dane wprowadzone do jednego z podsystemów (np. archiwum fotografii, archiwum tekstów opublikowanych) są dostępne dla innych podsystemów, w których są potrzebne; b) dane są zebrane we wspólnej bazie danych, do której mają dostęp wszystkie powiązane podsystemy [Zygała 2007: 58]; c) dane dają się łatwo wyszukiwać i ewidencjonować; d) korzystanie z systemu nie wymaga dodatkowego oprogramowania i szczególnych umiejętności informatycznych; e) dane są chronione przed nieuprawnionym dostępem, gdyż system umożliwia pozyskanie określonych informacji tylko zalogowanym użytkownikom; f) dane są chronione przed zniszczeniem dzięki central- 
nemu systemowi zabezpieczeń, np. przez tworzenie kopii zapasowych danych w celu zabezpieczenia ich na wypadek awarii sprzętu, błędów w oprogramowaniu czy błędów w obsłudze [Kolegowicz 2003: 65].

Istotnym zastosowaniem produktów z grupy CMS jest tworzenie platform pracy grupowej, opartych na ujednoliconej komunikacji, co można wykorzystywać w planowaniu i organizowaniu pracy zespołów reporterskich, pionu reklamy czy pionu graficznego, w zarządzaniu kampaniami marketingowymi i redakcyjnym public relations. Narzędzi CMS można bowiem używać do przygotowywania i realizacji konkretnych przedsięwzięć związanych z działalnością redakcji, takich jak kolegia redakcyjne, badania rynkowe, kampanie promocyjne itd. Internetowe platformy zespołowe umożliwiają ponadto np. kierowanie poszczególnymi działami redakcji czy koordynowanie współpracy między pionem redakcyjnym a działem reklamy. Głównym zadaniem platformy pracy grupowej jest zarządzanie czasem pracy i regulacja przepływu informacji między członkami zespołu realizującego określony projekt, a także monitorowanie go na każdym etapie. Do najczęstszych elementów tego typu platform należą: a) kalendarze - umożliwiają planowanie i organizowanie pracy własnej oraz innych członków zespołu przez przypisywanie zadań zgodnie z przyjętym harmonogramem i obłożeniem poszczególnych pracowników; b) komunikatory - gwarantują szybki obieg informacji drogą komunikacji tekstowej, głosowej i wideo dostępnej z poziomu komputera, iPoda czy telefonu komórkowego, umożliwiają prowadzenie telekonferencji, wykładów, e-learningu; c) bazy teleadresowe - pozwalają na szybki dostęp do bazy danych, zawierającej szczegółowe informacje o przedstawicielach różnych grup otoczenia wewnętrznego i zewnętrznego organizacji prasowo-wydawniczej (reklamodawcy, eksperci zewnętrzni, rzecznicy prasowi oraz inne źródła informacji, dziennikarze, współpracownicy, fotoreporterzy, graficy, pracownicy wydawnictwa i poligrafii), oraz na przetwarzanie danych zgodnie $z$ aktualnymi potrzebami (filtrowanie, katalogowanie, tworzenie list adresowych); d) bazy plików - umożliwiają pozyskanie informacji z rozmaitych baz funkcjonujących w ramach zintegrowanego systemu CMS (np. dane finansowe, kolportażowe, kadrowe); e) poczta e-mail - umożliwia odbiór, wysyłanie i magazynowanie listów elektronicznych oraz zintegrowanie kont pocztowych na różnych komputerach.

W praktyce funkcjonowania organizacji prasowo-wydawniczej szerokie zastosowanie mają ponadto aplikacje do zarządzania powierzchnią reklamową oraz kontaktami z klientami (przede wszystkim reklamodawcami 
i prenumeratorami). Narzędzia te pozwalają np. tworzyć i edytować cenniki reklam i ogłoszeń, monitorować zachowania konkretnych klientów (wartości zleceń, liczba ogłoszeń), automatycznie wyliczać i przyznawać rabaty, uwzględniać rozliczanie klienta według indywidualnego cennika, kontrolować płatności, fakturować usługi. Ułatwiają także przyjmowanie i realizację zleceń reklamowych przez określenie rozmiaru ogłoszenia, edycję treści, wybór czasu i formy emisji, planowanie oraz podgląd i edycję dostępnej powierzchni reklamowej na stronach gazety. Stanowią również instrument analizowania danych marketingowych dotyczących rynku reklamy (porównanie sprzedaży reklam w różnych tytułach: własnych i konkurencyjnych). Zaawansowane technicznie aplikacje dają działom reklamy i ogłoszeń możliwość samodzielnego makietowania oraz łamania gazetowych kolumn ogłoszeniowych - np. w systemie MediaPress, stosowanym m.in. przez „Dziennik Wschodni”, ,Gazetę Lubuską", , Nową Trybunę

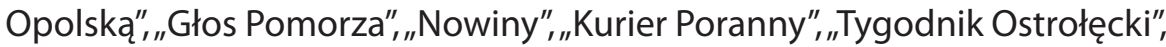
"Gazetę Olsztyńską” i „Express Bydgoski”, makietowanie stron ogłoszeniowych odbywa się za pomocą prostej techniki „przeciągnij i upuść" i polega na przeciąganiu ogłoszenia z listy przyjętych zleceń na siatkę modułową strony ogłoszeniowej i umieszczaniu go we wskazanym miejscu. Produktem końcowym makietowania jest wydruk rozkładu ogłoszeń na stronie wraz z listą zawierającą wszystkie potrzebne dane. W przypadku przyjmowania zleceń na ogłoszenia ze wskazaniem miejsca moduł może być wywołany automatycznie w trakcie wprowadzania zlecenia. System daje ponadto możliwość makietowania automatycznego wraz z określeniem kolejności makietowania ogłoszeń według ich cech (typu, rozmiaru, branży). Automakietowanie samoczynnie wypełnia kolumnę ogłoszeniową zleconymi reklamami, co pozwala na dużą oszczędność czasu i wygodę pracy. Wszystkie zamakietowane kolumny ogłoszeniowe są rejestrowane przez system $w$ bazie danych.

Coraz większą popularnością wśród menadżerów mediów cieszą się również aplikacje wspierające działania finansowo-księgowe organizacji prasowej, w tym najbardziej użyteczne w pionie redakcyjnym programy służące wyliczaniu honorariów autorskich (wierszówek). Narzędzia te, stosowane np. przez redakcje koncernu Media Regionalne, umożliwiają rejestrowanie publikowanych w gazecie artykułów i dokonywanie rozliczeń pracy dziennikarzy na podstawie takich kryteriów, jak objętość tekstu, miejsce publikacji czy rozmiar i rodzaj kosztów poniesionych przez autora. Wyliczanie wierszówek za pomocą oprogramowania komputerowego 
pozwala uzyskiwać istotne informacje raportowe, np. średnia wierszówka działów redakcji z podziałem na pracowników, analiza wierszówki z podziałem na tytuły, strony oraz działy itp.

Należy zauważyć, że zmiany technologiczne, wpływające na sposób organizacji pracy redakcji i proces przygotowania produktu medialnego, w coraz szerszym zakresie obejmują DTP oraz technologię druku. DTP (ang. Desktop Publishing) należy zdefiniować jako ogół czynności mających na celu przygotowanie na komputerze materiałów do powielenia metodami poligraficznymi. Realizacji tych czynności służy oprogramowanie komputerowe, wykorzystywane przede wszystkim do składu i łamania tekstu. W ciągu ostatnich lat nastąpił dynamiczny rozwój aplikacji z tej grupy. Starsze i mniej użyteczne narzędzia, np. z grupy Interleaf czy Ventura Publisher (Corel Ventura), są zastępowane nowoczesnym, funkcjonalnym i coraz łatwiejszym w obsłudze oprogramowaniem, np. Adobe PageMaker czy QuarkXPress (w 2007 roku pojawiła się pierwsza wersja programu kompatybilna z systemem Windows Vista i mająca interfejs w języku polskim; najnowsza wersja programu - QuarkXPress 8 - umożliwia m.in. bezpośrednią edycję obrazów, obsługę języków wschodnioazjatyckich, tworzenie animacji Flash).

W artykule zostały omówione jedynie wybrane obszary zastosowań nowoczesnych rozwiązań informatycznych w działalności redakcji prasowej. Na rynku produktów komputerowych przybywa propozycji adresowanych do wydawców gazet i czasopism. Dotyczy to zarówno pojedynczych aplikacji, przydatnych na poszczególnych etapach i odcinkach działalności organizacji prasowo-wydawniczej, jak i rozległych systemów informatycznych, wirtualizujących niemal całokształt procesów pracy w przedsiębiorstwie prasowym.

\section{Bibliografia}

Chyliński Marek, Russ-Mohl Stephan. 2008. Dziennikarstwo. Warszawa:Wydawnictwo Polskapresse.

Hofman Iwona. 2007. Polityka. Media. Społeczeństwo. Studia i szkice. Toruń: Wydawnictwo Adam Marszałek. 
Jung Bohdan, Kowalski Tadeusz. 2006. Media na rynku. Wprowadzenie do ekonomiki mediów. Warszawa: Wydawnictwa Akademickie i Profesjonalne.

Kolegowicz Konrad. 2003. Wartość informacji a koszty jej przechowywania i ochrony. [W:] R. Borowiecki, M. Kwieciński (red.). Informacja w zarzq̨dzaniu przedsiębiorstwem. Kraków: Wolters Kluwer.

Michalczyk Stanisław. 2006. Dziennikarstwo jako przedmiot refleksji naukowej. [W:] M. Gierula (red.). Współczesny dziennikarz i nadawca. Sosnowiec: Wydawnictwo Wyższej Szkoły Zarządzania i Marketingu.

Neffe llona. 2008. Systemy zarządzania treściq (CMS) szansq̨ dla rozwoju dziennikarstwa internetowego. Referat wygłoszony na 18. Ogólnopolskim Sympozjum Naukowym nt. „Komputer w edukacji”. Kraków: Uniwersytet Pedagogiczny im. Komisji Edukacji Narodowej.

Nowak Jakub. 2008. Internet w Polsce. [W:] L. Pokrzycka, B. Romiszewska (red.). Oblicza polskich mediów po 1989 roku. Lublin:Wydawnictwo Uniwersytetu Marii Curie-Skłodowskiej.

Podkański Wiesław. 2007. Siła rynku, „Press" nr 10, s. 68.

Smoczyński Wawrzyniec. 2009. Koniec wiadomości. „Polityka” nr 6.

Wolny-Zmorzyński Kazimierz, Kaliszewski Andrzej, Furman Wojciech. 2006. Gatunki dziennikarskie. Teoria, praktyka, język. Warszawa: Wydawnictwa Akademickie i Profesjonalne.

Zygała Ryszard. 2007. Podstawy zarządzania informacja w przedsiębiorstwie. Wrocław: Wydawnictwo Akademii Ekonomicznej we Wrocławiu.

\section{Źródła internetowe}

Enterprise Kontent Management. http://www.jade.pl/Documents/Enterprise\%20 Content\%20Management.doc, 17.10. 2009.

System MEDIAPress2. 2008. http://www.mediapress.pl/mediapress.htm, 11.07.2009. Wierszówka. http://www.soft4media.pl/projekty/aplikacje-web/wiersz, 11.07.2009. 